\title{
Indian Epic Hero Bhiṣma and Buddha
}

\section{Norio SEKIDO}

In the fourth chapter of the SDP, verse number 53 has been appeared the name of Bhissma;

adyo vayam śrāvaka-bhūta nātha

saṃśrāvaișyāmatha cāgra-bodhim/

bodhīya Śabdam ca prakāśayamas

teno vayaṃ śrāvaka Bhịsma-kalpāḥ//53//1)

"Now we are, in real, your disciples, taking the voice of supreme enlightenment, and causing all to listen the word of enlightement, for we are pure disciples like Bhịṣma."

But H. Kern claims "Bhịsma, the son of Sāntanu, was a great hero and sage, and it is by no means impossible that the word used in the text contains an allusion to that celebrated person, Bhisma as an epithet of Siva"2), and S. Matsunami follows Kern's opinion that it is no example to compare the virtue of śrāvaka in Buddhist scriptures with Hero Bhiṣma in the MBh which is one of the Sanskrit Epic literature. That is why it is no reason to appear Hero Bhișma of the $\mathrm{MBh}$ in the Buddhist text.

But we can not deny the scripts of the SDP, as far as reading the sanskrit text, the word of Bhisma is written. It is not rational to deny the facts. If it were mistakes of campiler at the process of compiling, we have to consider of the meaning of mistakes. Fortunately other evidences are available, there are no word for Bhiṣma in the chinese translations, which are of Dharmaraksita, Kumārajīva, Jñānagupta and others. Now how about Tibetan translations?

de-bas bdag-cag sgrogs-pa mi-bzad ḥdra

These are also no word for Bhịsma in Tibetan translation, Beijing. Lhasa, Derge, Conne, Nartan edition. But according to Tibetan translators, the 
Epic Hero Bhīsma and Budpha (SEKIDO)

original text must be Śrāvak-akṣiṇa-kalpāḥ or Śrāvakākṣinna-kalpāḥ

It means that therefore we are real disciples like having endless echo. M.E. Burnouf also dropped the name of Bhissma in his French translation ${ }^{3)}$. As a result, the word for Bhịsma has been appeared only in Sanskrit texts.

And in the first chapter of the SDP appears one follower of Brahmā ; evam pramukhair dvādaśabhiś ca brahmakāyika-devaputra-sahasraiḥ)

brahmakāyika, which means the member of Brahmakāya. therefore we can recognize some influences of the $\mathrm{MBh}$ in this chapter ${ }^{5}$.

The king and people loved him, but Bhișma had to face many family troubles. His step-brothers died one by one. He sacrificed himself and his desires for the goodness of the country and greatnees of the king. He took vow not to marry and he became great soul. From his father's death till his nephew's sons grew to be young prince, he was the beloved of all, a ruler who stood towering one all the kings of the Aryan land.

We should never forget the great poet Vyāsa, who wrote all parvas about Bhiṣma and also major parts of the Mahābhārata as after the birth of Buddha, the life in Kapilavastu, the father's kingdom, looked very happy and prosperous. Similarly Vyāsa says when Bhịsma became the ruler, the earth began to give harvests and crops also became of good flavour. The clouds began to pour rain in season, and the trees become full of flowers and fruits ${ }^{6}$. The draughts cattle were all happy, and the birds and the other animals rejoiced exceedingly. And the flowers became fragrant, and the fruits became sweet, and the cities and towns became filled with merchants and traders and artists of every description. And the people became brave, learned, honest and happy. There were no robbers then, nor anybody who was sinful. It seemed that the golden age had come upon every part of the kingdom. Bhissma and Buddha represent two contrasting facets.

Bhïsma was also very responsible statesman of his age. He was a godly man in the world. Buddha was a godly man in the forest. Now for the throne of Kuru kingdom. sacred and evil strategy occurred off and on. But 
Bhișma remained as great teacher and the onlooker. He [oved Arjuna, but always lived with the Kuru quarters. Like Bnddha. He kept his life well-disciplined and holy. By this time Krishna, the incarnation of god became famous and well-established. Bhiṣma had true faith in Krishna and his words. If great Bhiṣma were not there, it was quite evident that it would have been impossible for the Pạndus to perform their great sacrifice. Bhișma was the towering personality amongst all the kings of Aryavrata. Bhịsma stood at the head of all. Bhịsma was all in all in all matter. The great battle of the Mahābhārata, in spite Bhiṣma to display his greatest war efficiency and also his message as a great saint ${ }^{7}$. His life is full of holy words and great sacrifices. He comes nearer to Buddha in search of truth and $\operatorname{god}^{8)}$.

The detached and objective life and mind of this great hero-saviour, demonstrates the truest pattern of a great Buddhist follower. He knew every inch of 'mokșa' and the honesty of living on earth. He always kept himself aloof from women and the lechery.

In the $\mathrm{MBh}$, we come across many religious irreligious accidents. Bhīsma always emerged as a great teacher and as a great hero. In between the richness and the property of Yudhișțhira made a wicked Duryodhana mad with jealousy.

Blind Dhritarashtra foresaw the fatal result of this play, but after a good deal of arguement, he finally yielded and sent Vidura to bring the Panduavas to Hastinapura. Most unwillinglly Vidura went and delivered to Yudhișthira the king's message' .

Thus we can say the presence of Bhissma was the presence of godly right and law. As Buddha represented the defined law and divine truth, who preached the voice of sky on the earth. So people could rise from the slumber of Māyā and lechery. Mahāyāna Buddhism brought discipline and new meanings in life. They remained again and again that life may be happy not only the company of emotional pleasure, it also may be happy in the company of divinity.

As a result, we can acknowledge the doctrine of Boddhisattva ${ }^{10)}$ as well 
as the ideals of kshatriya warriors, who possibly kept the same goal. These aims show the svadharma without expecting fruitful results for only seeking practices, also as reflected in Gìtā. That aims to benefit others without expecting nirvāna only asking forgetting others enlightenment as possible as quickly.

1) Kern Nandjio edition, pp. 118-119.

2) Kern, H. The Saddharmapundarika or The Lotus of The True Law, SBES. Vol. XXI, Delhi, 1980, p. 115, 2 f.

3) Burnouf, M.E. le lotus De la Bonne Loi, Paris, 1973, p. 74

53 C'est aujourd'hui, ô Chef, que nous sommes devenus/ des Çrāvakas; aussi exposerons-nous l'éminent état

de Bôdhi; nous expliquerous le sens du mot de Bôdhi; aussi sommes-nous comme de redoutables Çrāvakas.

4) Kern Nandjio edition, p. 4.

5) 漢訳

筑法護訳 大正蔵 vol. 9, No. 263 p. 83a

我等今日 乃為聲聞

鳩摩羅什訳 大正蔵 vol. 9,No, 262 p. 18c

今得無漏 無上大果

我等今者 畺是聲聞

闇那崛多等訳 大正蔵 vol. 9, No. 264 p. 151b 我等令者 畺是罄聞

6) Bose, J.N. Bhīsma his life and teachings, Delhi, 1989, pp. 11-12

7) Srimad Bhagavad-gìtā, Chap. 4, 7 yadā yadā hi dharmasya

glānir bharati bhārata

pāritrāṇya sādhūnāṃ

vināšāya caduṣkṛtām

$$
\begin{gathered}
\text { abhiyutthānam adharmasya } \\
\text { tadā'tmānam sṛjāmyaham } \\
\text { dharmasaṃsthāpanārthāya } \\
\text { saṃbhavāmi yuge yuge }
\end{gathered}
$$

8) Sekido, Norio. A Study of the Mahāyanna Buddhism with special reference to the Saddharmapundirīka sütra and the Mahābhārata Bhīsma Parva and Śānti Parva, Ph. D, dissertation, University of Delhi, 1991, pp. 211-219.

9) Katz, Ruth Cecily. Arjuna in the Mahabhara, Delhi, 1990, pp. 156-169.

10) Mitomo, Ryojun. Saddharmapuṇḍarīka Sūtra: A Texual and Philosophical Study, Dissertation, University of Delhi, 1984, pp. 196-204

$<$ Key Words $>$ Bhīṣma, brahmakāyika, kshatriya, Warrior

(Research Fellow, The Eastern Institute; Ph. D.) 